\title{
Памяти Карла Молдахметовича Байпакова
}

\section{(C) 2019 г. Г.С. Джумабекова}

Казахстанская наука понесла невосполнимую утрату. В ноябре 2018 г. перестало биться сердце выдающегося археолога - Карла Молдахметовича Байпакова. Творческий путь исследователя начинается с альма-матер - университета с глубокими, стойкими традициями, воспитавшего плеяду известных специалистов. Становление и дальнейшая карьера К.М. Байпакова неразрывно связаны с отделом археологии Института истории, археологии и этнографии им. Ч.Ч. Валиханова, а с 1991 г. - переломного года в истории нашей страны - с созданием специализированного научного учреждения - Института археологии им. А.Х. Маргулана. Карл Молдахметович навсегда запомнится своей интеллигентностью, эрудированностью, сдержанностью, особым чувством юмора.

Ключевые слова: археология, К.М. Байпаков, археолог, отдел археологии Института истории, археологии и этнографии им. Ч.Ч. Валиханова, Институт археологии им. А.Х. Маргулана, организатор науки

23 ноября 2018 г. не стало Карла Молдахметовича Байпакова. Ученого, археолога, гражданина.

К.М. Байпаков родился в 1940 году в г. Талгар Алма-Атинской области в семье учителей. Окончив в 1963 г. кафедру археологии исторического факультета Ленинградского государственного университета, поступил в аспирантуру Института истории, археологии и этнографии им. Ч.Ч. Валиханова Академии наук Казахской ССР. В годы учебы Карлу Молдахметовичу посчастливилось слушать лекции известных ученых, признанных классиков советской археологии - М.И. Артамонова, М.П. Грязнова, Б.Б. Пиотровского, В.М. Массона.

Начав трудовую деятельность еще в 1966 г. в стенах ИИАЭ АН КазССР в качестве младшего научного сотрудника, Карл Молдахметович в сентябре 1991 г. возглавил Институт археологии им. А.Х. Маргулана.

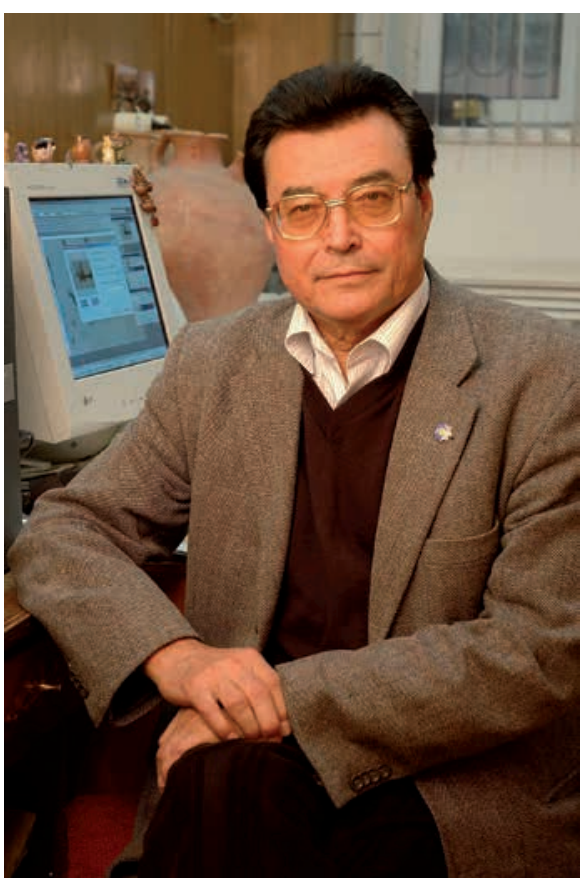

К.М. Байпаков, 2006 г. Фото О.В. Белялова

K.M. Baipakov, 2006. Photo by O.V. Belyalov 
Этапами научного пути стали кандидатская диссертация, подготовленная под руководством К.А. Акишева; докторская диссертации, а также высокие звания члена-корреспондента Национальной Академии наук РК (1994) и профессора археологии (1995), академика НАН РК (2003).

Свою жизнь К.М. Байпаков посвятил изучению городской культуры Южного Казахстана, взаимодействия города и степи, участвуя с 1963 г. в археологических экспедициях ЮжноКазахстанской комплексной археологической экспедиции (ЮККАЭ), с 1978 г. как руководитель казахской группы Казахско-Киргизской археологической экспедиции, с 1984 г. - начальник Таразской археологической экспедиции, затем - Археологической экспедиции Свода памятников и с 1989 г. - начальник ЮККАЭ.

ГородаКазахстана, величественные свидетели мощной цивилизации - Отрар, Куйрыктобе, Кок-Мардан, Мардан-Куик, Тараз, Костобе, Орнек, Луговое, Краснореченское, Талгар, Коялык сегодня известны во многом благодаря многолетним исследованиям под руководством К.М. Байпакова. Значителен вклад Карла Молдахметовича в изучение возраста города Алматы, его древней и средневековой истории.

Конечно, определенным символом и главным объектом многолетних исследований К.М. Байпакова и археологов сначала отдела археологии ИИАЭ АН КазССР, затем Института археологии им. А.Х. Маргулана был город Отрар и Отрарский оазис одноимённой археологической экспедицией (1969) и Южно-Казахстанской комплексной археологической экспедицией (1971). Среди наиболее известных открытий, получивших известность в

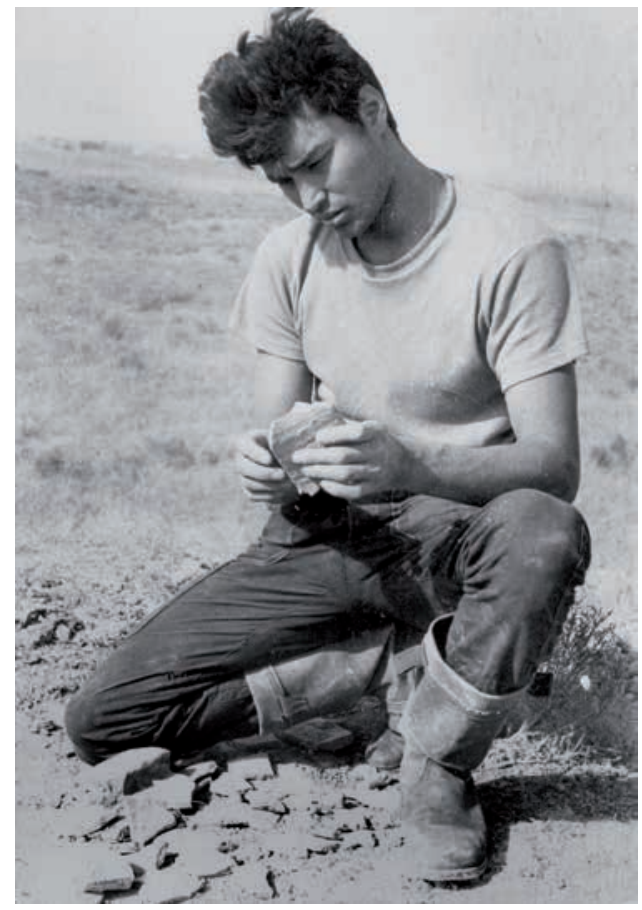

K.M. Байпаков на Oтраре, 1962 2. Фото О.В. Медведева

K.M. Baipakov at the Otrar, 1962. Photo by O.V. Medvedev

ближнем и дальнем зарубежье, следует назвать также изучение дворцового комплекса на городище Куйрыктобе с уникальным резным деревом, свидетельствующим о высокой художественной культуре населения; раскопки Костобе, отождествляемого со средневековым Джамукатом, прославившимся удивительной художественной резьбой по глине; выявление и раскопки буддийского храма на городище Коялык; исследование буддийского монастыря-крепости Аблайкит. Благодаря длительным скрупулезным раскопкам на средневековых памятниках, в Казахстане сложилась своя археологическая школа.

К.М. Байпаков являлся ведущим специалистом в области средневековой археологии не только Казахстана, но и Центральной Азии. Он внес не- 


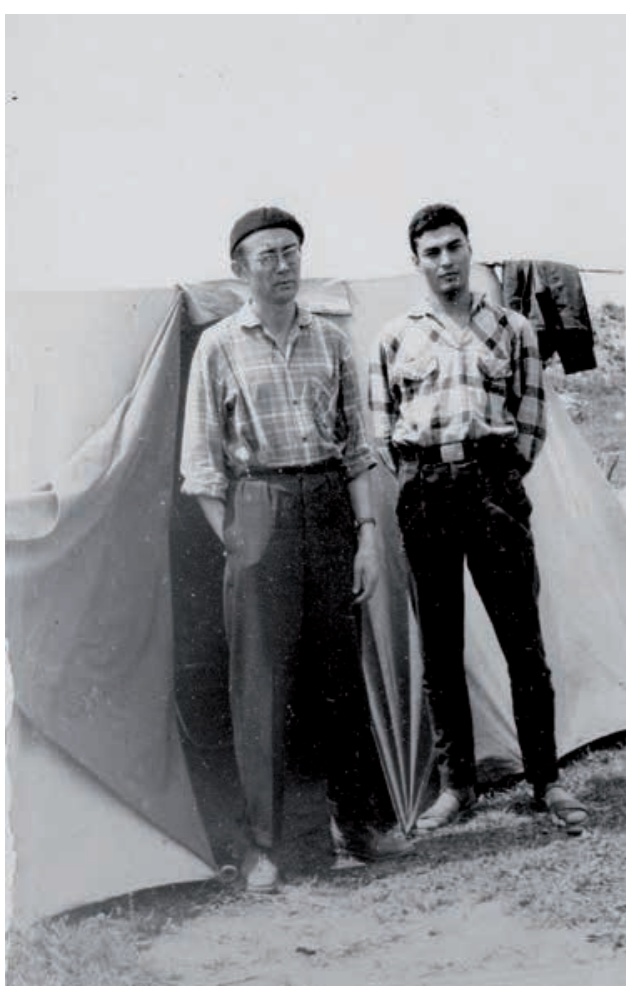

Учитель и ученик. К.А. Акишев и К.М. Байпаков, 1964 г. Городище Сумбе

K.A. Akishev and K.M. Baipakov, 1964. Sumbe settlement

оценимый вклад в изучение кангюйской проблемы, истории Караханидов, средневековых городов Казахстана, взаимосвязи города и степи, кочевых и оседлых цивилизаций, в охрану памятников археологии. В сферу интересов К.М. Байпакова входили также проблемы исторической географии, вопросы духовной культуры и религиозных воззрений населения региона в древности и средние века, тюркской цивилизации.

Неразрывно связано с проблемой города и степи изучение феномена Великого Шелкового пути, его исторического пространства, которому К.М. Байпаков посвятил годы своей жизни.
В 1989 году К.М. Байпаков возглавил Археологический центр ИИАЭ, в 1991 г. - впервые созданный в Казахстане Институт археологии им. А.Х. Маргулана. Под руководством академика К.М. Байпакова Институт археологии им. А.Х. Маргулана МОН РК успешно реализовал Государственную программу «Культурное наследие: памятники археологии», а также «Национальная идея».

К.М. Байпаков, возглавляя фундаментальные научные исследования Института археологии им. А.Х. Маргулана, осуществлял их в тесном сотрудничестве со специалистами различных научных центров Республики Казахстан: Евразийского университета им. Л.Н. Гумилева, СевероКазахстанского университета, Казахского государственного национального университета им. аль-Фараби, Карагандинского государственного университета им. академика Е.А. Букетова, а также России, Кыргызстана, Франции, Бельгии, Италии, Японии, Кореи, США. Программы, выполняемые Институтом археологии им. А.Х. Маргулана, охватывали широкий спектр научных исследований от полевых археологических работ до теоретического моделирования и реконструкции палеоэкологической обстановки и системы жизнеобеспечения населения в эпоху камня, хозяйственно-культурных процессов, вопросов, идеологии и искусства в бронзовом веке, исторического процесса на территории Казахстана от раннего железного века до эпохи средневековья.

Результаты исследований К.М. Байпакова нашли отражение в научных трудах - монографиях и статьях, в которых разработаны вопросы развития отрарско-каратауской куль- 


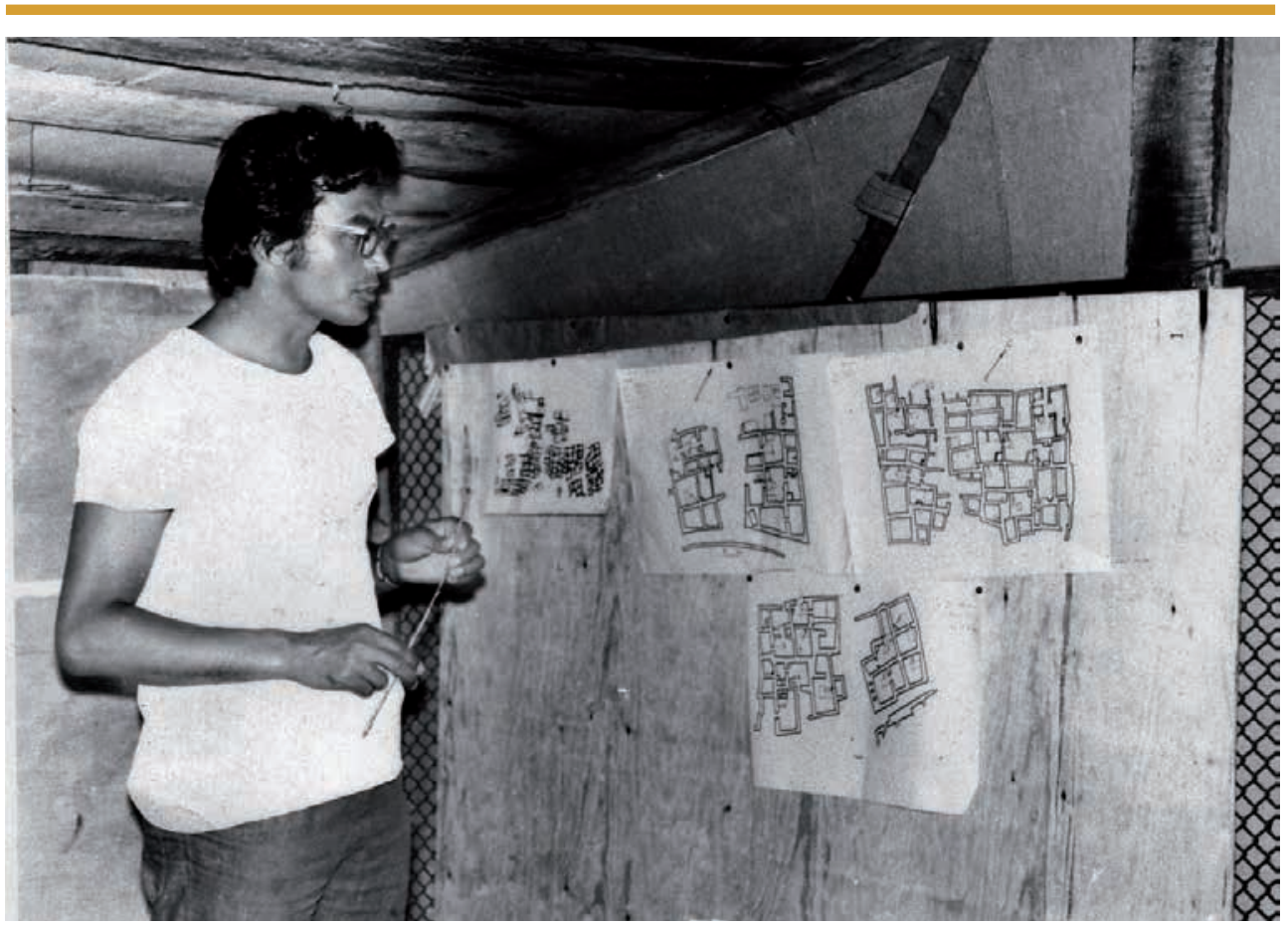

К.М. Байпаков докладывает о ходе раскопок. Отрар, лето 19712. Фото О.В. Медведева

K.M. Baipakov reports about the excavation. Otrar, summer 1971. Photo by O.V. Medvedev

туры на Сырдарье; развития городов и городской культуры Южного Казахстана и Жетысу; взаимодействия и взаимовлияния города и степи, решены актуальные проблемы истории Шелкового пути, представлены методические разработки по ряду насущных тем.

К.М. Байпаковым опубликовано более 100 авторских и коллективных монографий, альбомов, каталогов, учебников и учебных пособий, свыше 700 научных и научно-популярных статей и заметок в газетах и журналах, как в Казахстане, так и в России, Узбекистане, странах дальнего зарубежья - Франции, Германии, Южной Корее, Китае, Пакистане, Италии, США.

К.М. Байпаков издал ряд фундаментальных исследований, в том числе результаты важнейших разработок по вопросам урбанизации Казахстана
(2012, 2013, 2014, 2016). К.М. Байпаков внес свой весомый вклад в развитие музейного дела и охрану памятников, приняв участие в создании Музея археологии АН КазССР, экспозиций областных историко-краеведческих музеев в гг. Шымкенте и Таразе, Отрарского музея-заповедника в с. Шаульдер, издании первого тома «Свода памятников истории и культуры Казахстана (Южно-Казахстанская область)» (1994). К.М. Байпаков возглавлял работы по созданию 10-ти томного «Свода памятников истории и культуры Республики Казахстан».

К.М. Байпаков в соавторстве с К.А. Акишевым выпустил первый учебник для вузов по археологии Казахстана (1979); а также участвовал в написании учебных пособий для вузов (1993, 2006, 2007). Карл Молдахметович являлся автором разделов 
многотомных изданий Истории Казахской ССР и Истории Казахстана, учебников по истории для учащихся средних школ.

Конечно, К.М. Байпаков передавал свои знания и опыт студентам, соискателям, докторантам, молодым ученым, в том числе осуществлял руководство в подготовке кандидатских и докторских диссертаций.

K.M. Байпаков представлял успехи и достижения казахстанской археологии мировому научному сообществу в докладах на многочисленных международных и республиканских совещаниях и конференциях, в числе которых VII Генеральная Ассамблея «ИКОМОС» в Дрездене, III советско-американский симпозиум в Вашингтоне, а также на лекциях для студентов и симпозиумах в Токио,
Сеуле, Париже, Анкаре, Вашингтоне, Тегеране, Лахоре, Пекине, Риме, Венеции... .

В 1998 г. К.М. Байпакову было присвоено звание Заслуженного деятеля науки и техники Республики Казахстан, он являлся лауреатом премии им. Ч.Ч. Валиханова (1988), членом научного общества Дунхуано-Турфановедения (с 1992 г.), Казахского Национального комитета «Великий Шелковый путь» (с 1991 г.), членом Международного комитета ЮНЕСКО по подготовке шеститомной «Истории цивилизации Центральной Азии» (с 1991 г.), руководителем секции «Памятники археологии» Общественного совета по реализации Государственной программы «Культурное наследие», международным экспертом ЮНЕСКО про-

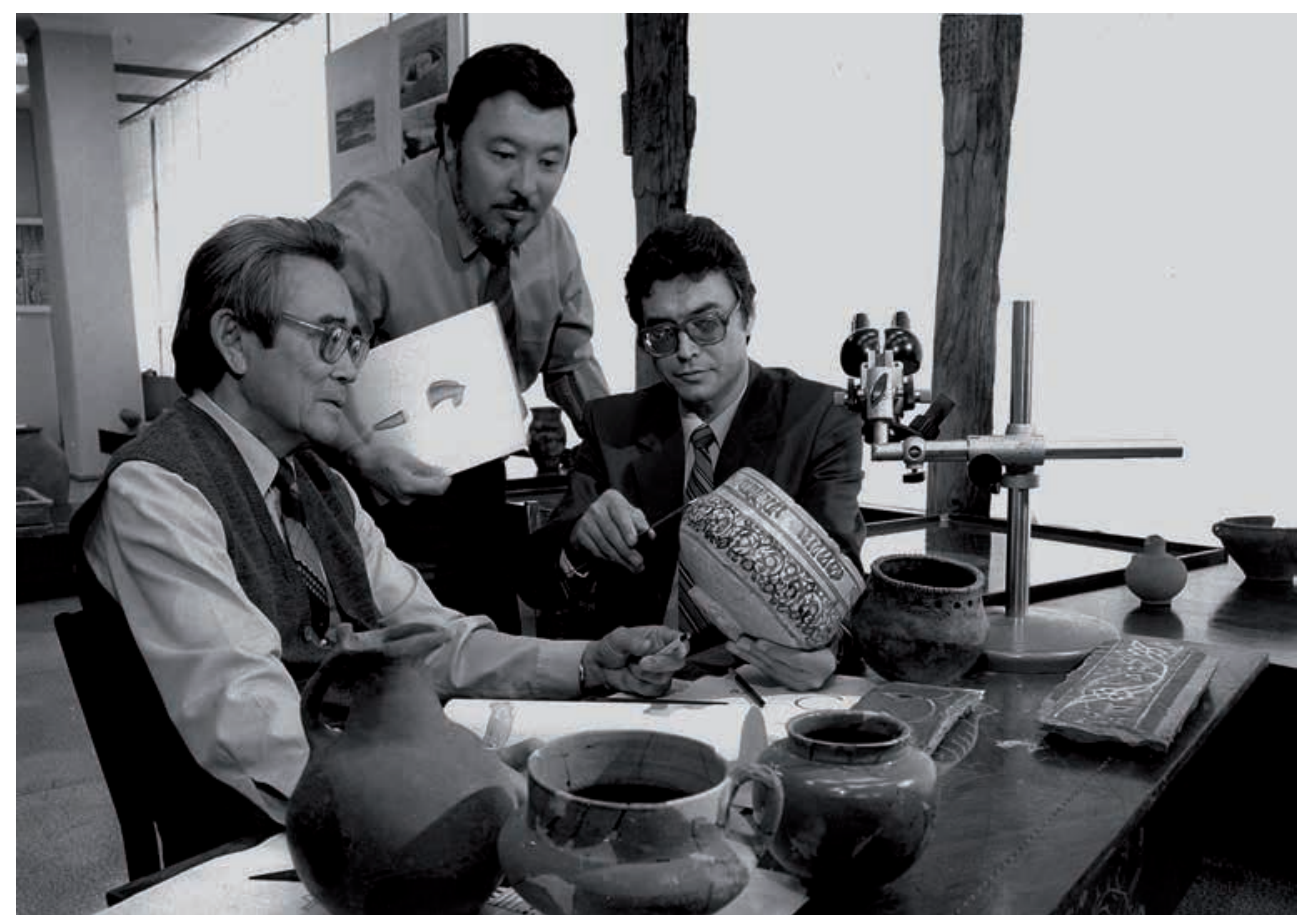

К.А. Акишев, С.М. Ахинжанов, К.М. Байпаков изучают находки из Отрара. Музей АН КазССР. Август, 1973 г. Фото из семейного архива К.М. Байпакова

K.A. Akishev, S.M. Akhinjanov, K.M. Baipakov study finds from Otrar. Museum of the Kazakh SSR. August 1973. Photo from the family archive of K.M. Baipakov 
екта Казахстан-ЯпонияЮНЕСКО «Сохранение древнего городища Отрар» (2001-2004), по подготовке трансграничной номинации «Великий Шелковый Путь: Китай - Центральная Азия»; членом Высшей научнотехнической комиссии при Правительстве Республики Казахстан и Комиссии по присуждению Государственных премий Республики Казахстан; академиком Академии социальных наук Республики Казахстан, членомкорреспондентом Германского археологического Института (Германия, г. Берлин), членом Международного комитета ЮНЕСКО по подготовке многотомной

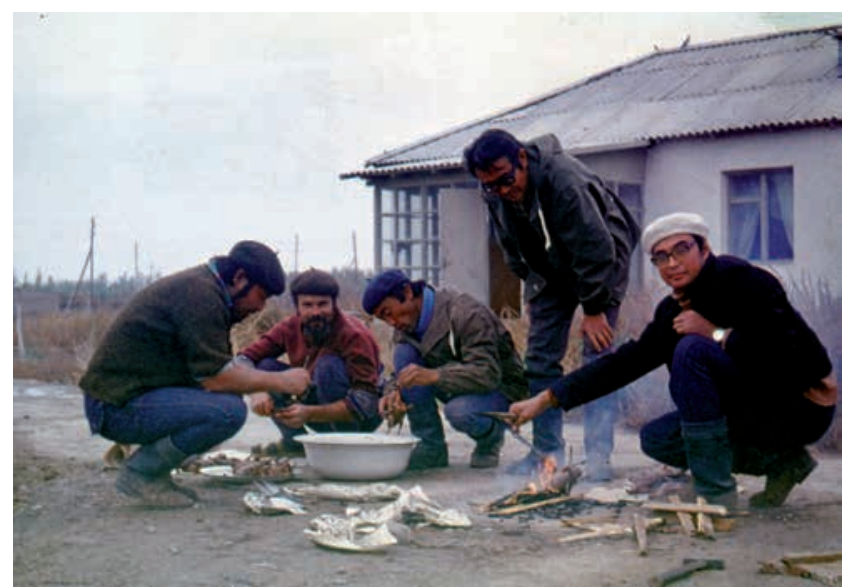

Отрар. Археологическая база в с. Шаульдер, начало 1980-х г2. Слева-направо: С.М. Ахинжанов, В.А. Грошев, Б.Н. Нурмуханбетов, К.А. Акишев, К.М. Байпаков

Otrar. Archaeological base in Shaulder, early 1980s. From left to right: S.M. Akhinjanov, V.A. Groshev, B.N. Nurmukhanbetov, K.A. Akishev, K.M. Baipakov

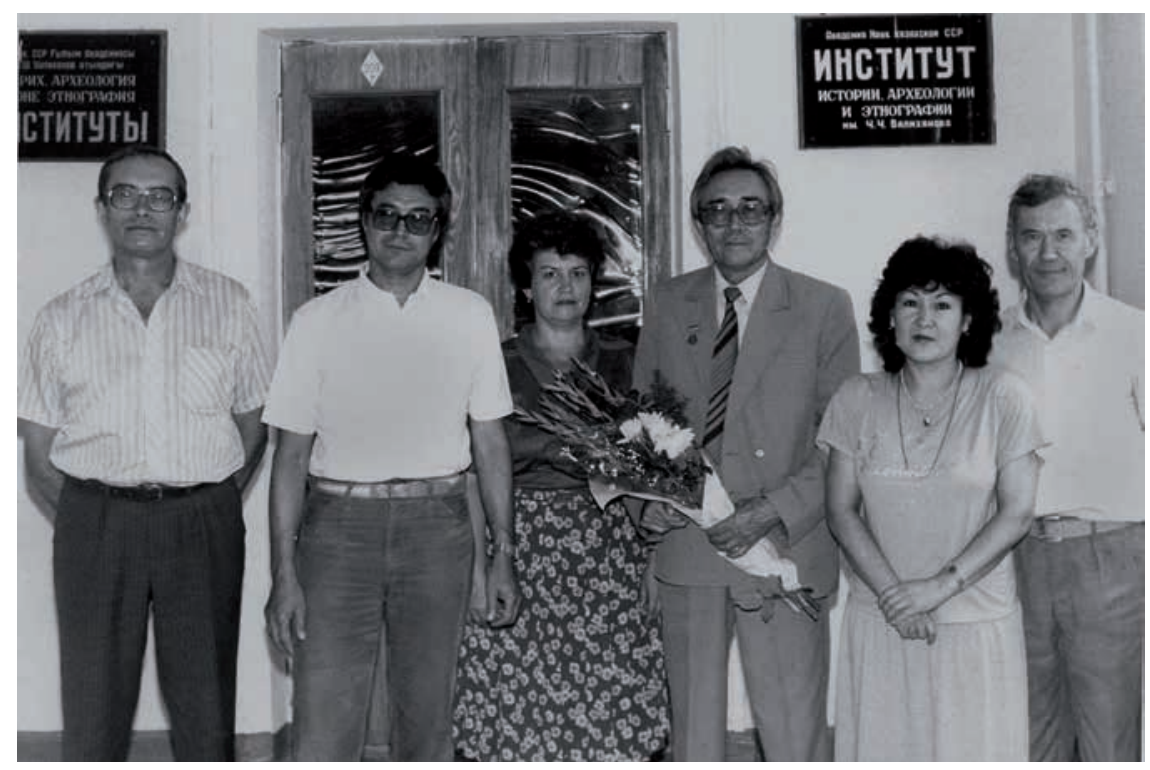

После награждения К. А. Акишева знаком «Заслуженный деятель науки». Слева направо: Л.Б. Ерзакович, К.М. Байпаков, Т.В. Савельева, К.А. Акишев, Р.А. Бектуреева, М.Х. Ильтаев. Август, 1989 г. Фото О.В. Медведева

After awarding K.A. Akishev with the "Honored Worker of Science" sign. From left to right: L.B. Erzakovich, K.M. Baipakov, T.V. Savelieva, K.A. Akishev, R.A. Bektureeva, M.Kh. Iltaev. August, 1989. Photo by O.V. Medvedev 
служенный деятель науки и техники Республики Казахстан (1998 г.), кавалер ордена Республики Казахстан «Парасат» (2003), ордена «Барыс» III степени (2010), обладатель нагрудного знака «За вклад в развитие науки РК» (2002), победитель 5 конкурса «Алтын-Адам» и Фестиваля «Выбор года» в номинации «Деятель науки» (2005). Награжден медалью ЮНЕСКО «За вклад в изучение Великого Шелкового пути - пути диалога культур и вклад в мировую науку» (2005), межгосударственным дипломом и памятным знаком за вклад в изучение духовного развития мусульманских стран Экономического Содружества в номинации «История, культура, литература и изобразительное искусство» (2006), серебряной медалью им. А. Байтурсынова Ассоциации вузов Республики Казахстан «Лучший автор» (2008), является лауреатом Независимой премии «Платиновый Тарлан» в номинации «Наука и просвещение РК» (2007), лауреат государственной премии Республики Казахстан в области науки и техники имени аль-Фараби (2017).

Последние годы К.М. Байпаков возглавлял «Центр сближения культур» Министерства культуры и спорта РК.

Сухие строки биографии отражают плодотворную, насыщенную творческую, научную жизнь К.М. Байпакова. Но умалчивают о его человеческих качествах, то, каким запомнился нам, археологам, Карл Молдахметович. 


\section{Список основных публикаций академика НАН РК К.М. Байпакова*}

\section{Авторефераты:}

1. Средневековые города и поселения Семиречья (VII-XII вв.): автореф. дисс. ... канд. ист. наук. Алма-Ата: Институт истории, археологии и этнографии им. Ч.Ч. Валиханова, 1966. 22 с.

2. Средневековая городская культура Южного Казахстана и Семиречья в VI начале XVIII в. (динамика и основные этапы развития): автореф. дисс. ... докт. ист. наук. М.: Институт археологии АН СССР, 1985. 48 с.

\section{Монографии, книги-альбомы:}

1. Западнотюркский и Тюргешский каганаты: тюрки и согдийцы, степь и город. Алматы: Археологическая экспертиза, 2010. 398 с. с илл. (на каз., рус. яз.).

2. Археологическое культурное наследие г. Алматы. Алматы: Археологическая экспертиза, 2010. 164 с. (на каз., рус., англ. яз.).

3. Исламская археологическая архитектура и археология Казахстана. АлматыСамарканд: МИЦАИ, 2012. 284 с., илл. (на каз., рус. и англ. яз.).

4. Урбанизация Казахстана в эпоху бронзы - раннем средневековье // Древняя и средневековая урбанизация Казахстана (по материалам исследований ЮжноКазахстанской комплексной археологической экспедиции). Алматы, 2012. Кн. 1. 390 с., илл., цв. вкл.

5. Урбанизация Казахстана в IX - начале XIII в. // Древняя и средневековая урбанизация Казахстана (по материалам исследований Южно-Казахстанской комплексной археологической экспедиции). Алматы, 2013. Кн. II. 516 с., цв. илл.

6. Урбанизация Казахского ханства во второй половине XV - XVIII в. // Древняя и средневековая урбанизация Казахстана (по материалам исследований ЮжноКазахстанской комплексной археологической экспедиции). Алматы, 2014. Кн. III, ч. 2.534 с., илл.

7. Урбанизация в XIII - первой половине XV в. // Древняя и средневековая урбанизация Казахстана (по материалам исследований Южно-Казахстанской комплексной археологической экспедиции). Алматы, 2016. Кн. III, ч. 1. 596 с., илл.

8. Древнее золото Казахстана. Курган Иссык: фотоальбом. Астана: ОФПТИ «ALAU», 2013. 144 с. (на англ., рус. яз.) (фото О.В. Белялова).

9. Все дороги ведут в Туркестан. Памятники. Персоны. Алматы, 2013. 266 с., цв. илл. (в соавт. с Азимхан А.).

10. Петроглифы Малого Каратау и западной оконечности Киргизского Алатау. Алматы, 2013. 120 с., цв. илл. (в соавт. с Марьяшевым А.Н.).

11. Сокровища древнего и средневекового Тараза и Жамбылской области. Алматы, 2013. 320 с., цв. илл. (на каз., рус., англ. яз.) (в соавт. с Капековой Г.А., Воякинымм Д.А., Марьямевым А.Н.).

12. Выдающиеся археологические памятники Казахстана. Алматы, 2014. 504 с., илл. (в соавт. с Воякиным Д.А.).

13. Монетное дело и денежное обращение в Великой Монгольской империи, государствах Чагатаидов и Джучидов на территории Казахстана. Алматы, 2014. 264 с., ил. (в соавт. с Петровым П.Н., Воякиным Д.А.).

14. Могильник Каратума. Некрополь раннего железного века в Семиречье. Алматы: Археологическая экспертиза, 2016. 672 с., ил. (в соавт. с Воякиным Д.А., Захаровым С.В.).

15. Археологические исследования городищ Пшакшитобе и Бесиншитобе в Отрарском оазисе. Алматы, 2017. 160 с., илл. (на каз., рус., англ. яз.) (в соавт. с Авизовой А.К., Акылбек С.Ш.). 
16. Потенциальное влияние объектов всемирного наследия на образование в духе глобальной гражданственности в Республике Казахстан. Пособие для преподавателей общеобразовательных учебных программ основного среднего и общего среднего образования. Алматы: АРCEIU, НКВН, 2017. 122 с., илл. (в соавт. с Воякиным Д. А., Диканем М.Е., Масановым М.Н., Сарсеновой Э.А., Шайгозовой Ж.Н.).

17. История военного искусства Казахстана: фортификация древних и средневековых городов Южного Казахстана (по материалам археологических исследований округов Фараб-Отрар и Шавгар-Туркестан). Алматы: Институт археологии им. А.Х. Маргулана, 2017. 164 с., илл. (на каз., рус., англ. яз.). (в соавт. с Камалдиновым И.Р.).

18. История религий в Казахстане (древность и средневековье). Алматы: Servis Press, 2018.553 с., 567 илл. (в соавт. с Ерофеевой И.В., Казизовым Е.С., Терновой Г.А.).

\section{Участие в книгах:}

1. Свод памятников истории и культуры Жамбылской области. Жамбылский район. Алматы: Археологическая экспертиза, 2010. (на каз., рус. яз.).

2. Из истории изучения археологического и культурного наследия Отрара, Отрарского оазиса и Казахстана // Кузнецова О.В. Древности Отрара и Отрарского оазиса, Казахстана и Евразии (ЮККАЭ). Научные биографии участников и библиография исследований: матер. междунар. научн.-практ. конф., посвящ. 40-летию работ ЮККАЭ (Шаульдер, 18-19 октября 2011 г.). Алматы, 2014. С. 11-49.

3. Казахстан. Традиционные верования и шаманизм // Религии Центральной Азии и Азербайджана. Самарканд: МИЦАИ, 2016. Т. І. С. 9-92 (в соавт. с Терновой Г.А.).

\section{Статьи:}

1. Тенденции и перспективы развития археологии Казахстана // Казахстан и Евразия сквозь века: история, археология, культурное наследие: сб. научн. тр., посвящ., 70-летию К.М. Байпакова. Алматы: Археологическая экспертиза, 2010. С. 67-88.

2. Урбанизация в древнем и средневековом Казахстане // Традиции древней и средневековой городской культуры Средней Азии. 70 лет кафедре археологии Национального университета Узбекистана. Ташкент, 2010. С. 6-9.

3. Арабское завоевание и исламизация Южного Казахстана // Известия НАН РК. Сер. обществ. наук. 2010. № 1(274). С. 91-100.

4. Изучение, сохранение и использование культурного наследия в Казахстане // Совещание региональных специалистов. Культурное наследие Центральной Азии и вклад Японии (гг. Ташкент-Самарканд, 12-16 марта 2008 г.). Токио, 2010. С. 73-101 (в соавт. с Воякиным Д.А.).

5. Исследование городища Дженд // Известия НАН РК. Сер. обществ. наук. 2010. № 1 (274). С. 100-122 (в соавт. с Воякиным Д.А., Умарходжиевым А.А.).

6. Алматы - 1000 лет // Алматы. История тысячелетия: матер. междунар. научн.-практич. конф. «Древняя и средневековая урбанизация Евразии: взаимодействие, развитие и возраст города Алматы» (г. Алматы, 17-18 ноября 2010 г.). Алматы, 2012. Вып. 3. С. 8-18 (в соавт. с Савельевой Т.В.).

7. Отырар және оның маңындағы қазбаларының кейбір нәтижелері // Отырар. Тарихи-мәдени, ғылыми-танымдық журнал. 2013. № 1 (2). 5-11 б. (в соавт. с Алдабергеновым Н.О.).

8. Жилая застройка Отрара X-начала ХІІІ в. // Известия НАН РК. Серия обществ. и гум. наук. 2013. № 3. С. 174-186 (в соавт. с Воякиным Д.А., Акылбек С.Ш.). 
9. Изучение городища Оксыз // Известия НАН РК. Сер. обществ. и гум. наук. 2013. № 3. С. 133-147 (в соавт. с Камалдиновым И.Р.).

10. Жетытобе - курганы сакских царей // Промышленность Казахстана. 2013. № 2. С. 94-98 (в соавт. с Воякинылм Д., Сейткалиевымм М.).

11. Учитель // Диалог культур Евразии в археологии Казахстана: сб. научн. ст., посвящ. 90-летию со дня рождения выдающегося археолога К.А. Акишева. Астана, 2014. C. 21-22.

12. Учитель // Восхождение к вершинам археологии: сб. матер. междунар. научн. конф. «Древние и средневековые государства на территории Казахстана», посвящ. 90-летию со дня рождения К.А. Акишева. Алматы: Институт археологии им. А.Х. Маргулана, 2014. С. 9-20.

13. Города и поселения Казахского ханства // Восхождение к вершинам археологии: сб. матер. междунар. научн. конф. «Древние и средневековые государства на территории Казахстана», посвящ. 90-летию со дня рождения К.А. Акишева. Алматы: Институт археологии им. А.Х. Маргулана, 2014. С. 343-383.

14. Концепция становления исторического сознания в Республике Казахстан и задачи отечественной археологии (к подготовке 10-ти томной истории казахов и Казахстана) // Известия НАН РК. Сер. обществ. и гум. наук. 2014. № 5. С. 226-232.

15. Локализация городов Казахского ханства // Известия НАН РК. Сер. обществ. и гум. наук. 2014. № 5. С. 75-133.

16. Городище Сыгнак: мавзолеи // Известия НАН РК. Сер. обществ. и гум. наук. 2014. № 5. С. 45-51 (в соавт. с Акылбек С.Ш., Воякиным Д.А., Жолдасбаевым С.Ж.).

17. Геоинформационные системы как инструмент защиты и анализа археологического наследия Республики Казахстан // Известия НАН РК. Сер. обществ. и гум. наук. 2014. № 5. С. 195-206 (в соавт. с Воякиным Д.А., Амировым Е.Ш., Сейткалиевымм M.K.).

18. Города Казахского ханства // 550-летие Казахского ханства - судьбоносный этап национальной истории: сб. матер. научн.-практ. конф. (Астана, 16 февраля 2015 г.). Астана: Сенат Парламента РК, 2015. С. 52-66.

19. Об этническом составе населения городов Казахского ханства // Казахское ханство в потоке истории: сб. научн. ст., посвящ. 550-летию образования Казахского ханства. Алматы: Институт археологии им. А.Х. Маргулана, 2015. С. 19-49.

20. Раскопки городища Пшакчитобе и Бесиншитобе в Отрарском оазисе // Известия НАН РК. Сер. обществ. и гум. наук. 2015. № 6. С. 182-214 (в соавт. с Авизовой A.K.).

21. Торговля и денежное обращение в городах Казахского ханства в XVXVIII вв. // Казахское ханство в потоке истории: сб. научн. ст., посвящ. 550-летию образования Казахского ханства. Алматы: Институт археологии им. А.Х. Маргулана, 2015. С. 73-110 (в соавт. с Бурнашевой Р.3.).

22. Кескен Куюк-кала - столичный центр огузов // Казахское ханство в потоке истории: сб. научн. ст., посвящ. 550-летию образования Казахского ханства. Алматы: Институт археологии им. А.Х. Маргулана, 2015. С. 214-228 (в соавт. с Воякинылм Д.А., Ильинымм Р.В.).

23. О локализации городов Илийской долины Казахстана в XIII-XIV вв. // Казахское ханство в потоке истории: сб. научн. ст., посвящ. 550-летию образования Ка- 
захского ханства. Алматы: Институт археологии им. А.Х. Маргулана, 2015. С. 229270 (в соавт. с Савельевой Т.В.).

24. Изучение культурного наследия Казахстана. Взаимодействие Республики Казахстан и ЮНЕСКО: изучение культурного наследия и укрепление межкультурного диалога в целях сближения культур // Модернизация общественного сознания: модель Нурсултана Назарбаева: матер. научн.-практ. конф. Астана: Министерство культуры и спорта Республики Казахстан, 2017. С. 36-38.

25. Сержан Ахинжанов - выдающийся археолог и востоковед Казахстана // Археологическое наследие Центрального Казахстана: изучение и сохранение: сб. научн. ст., посвящ. 70-летию организации Центрально-Казахстанской археологической экспедиции Академии наук Казахстана. Алматы: НИЦИА «Бегазы-Тасмола», 2017. T. I. C. $174-180$.

26. Тамгообразные знаки на керамике с памятников Отрарского оазиса доарабской эпохи // Поволжская археология. 2017. № 3 (21). С. 155-167 (в соавт. с Авизовой А.К.).

27. Средневековые городища на северо-каратауском участке Великого Шелкового пути // Известия НАН РК. Сер. обществ. и гум. наук. 2017. № 1 (311). С. 160-167 (в соавт. с Воякиным Д.А.).

28. Архитектурно-археологический комплекс Акыртас // Археология Казахстана. 2018. № 1-2. С. 116-130.

29. Международная научно-практическая конференция «Центральная Азия на Великом Шелковом пути: диалог культур и конфессий от древности до современности» // Народы и религии Евразии. 2019. № 1 (18). С. 129-134 (в соавт. с Дашковским П.К.).

\section{Литература о жизни и деятельности академика НАН РК, д.и.н. К.М. Байпакова:}

1. Байпаков Карл Молдахметович // Промышленность Казахстана. 2018. № 3 (104). С. $90-92$.

2. Дашковский П.К., Савельева Т.В. Байпаков Карл Молдахметович - выдающийся ученый и организатор науки Казахстана // Народы и религии Евразии. 2019. № 2 (19) (в печати).

3. Карл Молдахметович Байпаков. Биобиблиографический указатель. Сост. О.В. Кузнецова. Алматы: Институт археологии им. А.Х. Маргулана МОН РК, 2000. 52 c.

4. Карл Молдахметович Байпаков. Материалы к биобиблиографии ученых Казахстана. Гл. ред. М.Ж. Журинов. Отв. ред. Б.Е. Кумеков. Сост. Т.В. Савельева, Д.А. Воякин. Алматы: Институт археологии им. А.Х. Маргулана; Археологическая экспертиза, 2010. 52 с.

5. Карлу Молдахметовичу Байпакову - 75 лет // Известия НАН РК. Сер. обществ. и гум. наук. 2015. № 6. С. 243-244.

6. Кумеков Б.Е., Воякин Д.А. Взгляд, меняющий науку. Карлу Молдахметовичу Байпакову - 75 лет // Вестник НАН РК. 2015. № 6. С. 229-232.

\section{Сведения об авторе:}

Джумабекова Гульнара Саиновна - кандидат исторических наук, ведущий научный сотрудник, Институт археологии им. А.Х. Маргулана (г. Алматы, Казахстан); gdzhuma@mail.ru

*Приводится список основных публикаций за 2010-2019 гг., составленный д.и.н. Т.В. Савельевой. По работам, изданным ранее, существует два биобиблиографических указателя, изданных в 2000 и 2010 гг. (см. выше). 


\section{Карл Молдахметұлы Байпақовтың рухына Г.С. Жұмабекова}

Қазақстан ғылымы орны толмас қайғыға ұшырады. 2018 жылдың қараша айында көрнекті археолог Карл Молдахметұлы Байпақовтың жүрек соғысы тоқтады. Зерттеушінің творчестволық жолы белгілі мамандардың қатарын тәрбиелеген терең де тұрақты дәстүрі бар университеттен басталды. К.М. Байпақовтың қалыптасуы мен одан кейінгі еңбек жолы Ш.Ш. Уәлиханов атындағы Тарих, археология және этнография институтының археология бөлімімен, ал 1991 жылдан бастап біздің еліміздің тарихындағы сыни жылда құрылған арнайы ғылыми мекеме Ә.Х. Марғұлан атындағы Археология институтымен тікелей байланысты. Карл Молдахметұлы өзінің жоғарғы білімділігімен, тәрбиелілігімен, ұстамдылығымен, ерекше қалжыңымен мәңгі есте қалады.

Түйін сөздер: археология, К.М. Байпақов, археолог, Ш.Ш. Уәлиханов атындағы Тарих, археология және этнография интитутының археология бөлімі, Ә.Х. Марғұлан атындағы Археология институты, ғылымды ұйымдастырушы

\section{To the memory of Karl M. Baipakov \\ G.S. Jumabekova}

Kazakhstan science has suffered a grievous loss. In November 2018, the heart of an outstanding archaeologist, Karl M. Baipakov, stopped beating. The creative development of the researcher began with the alma mater - a university with deep, enduring traditions, that brought up a galaxy of eminent specialists. Establishment and further career of K.M. Baipakov were intimately connected with the Department of Archaeology of Ch.Ch. Valikhanov Institute of History, Archaeology and Ethnography, and since 1991 - a turning point in the history of our country - with the creation of a specialized scientific institution - A.Kh. Margulan Institute of Archaeology. Karl M. Baipakov will forever be remembered for his intelligence, erudition, restraint, and special sense of humor.

Keywords: archaeology, K.M. Baipakov, archaeologist, Department of Archaeology of Ch.Ch. Valikhanov Institute of History, Archaeology and Ethnography, A.Kh. Margulan Archeology Institute, science organizer

\section{About the Author:}

Jumabekova Gulnara S. Candidate of historical sciences, leading researcher, A.Kh. Margulan Archeology Institute, Almaty, Kazakhstan; gdzhuma@mail.ru 